\title{
Hemşirelik Öğrencilerinin Hastaların Kişisel Sağlık Verilerinin Kayıt ve Korunmasına İlişkin Tutumları
}

\author{
Sevgi PAKIŞ ÇETIN ${ }^{1}$,(10) Kıvan ÇEVIK
}

${ }^{1}$ Arş. Gör., Manisa Celal Bayar Üniversitesi Sağlık Bilimleri Fakültesi, Hemşirelik Esasları Anabilim Dalı, Uncubozköy Kampüsü/Manisa

${ }^{2}$ Doç. Dr., Manisa Celal Bayar Üniversitesi Sağlık Bilimleri Fakültesi, Hemşirelik Esasları Anabilim Dalı, Uncubozköy Kampüsü/Manisa

\section{$\ddot{O} \mathbf{z}$}

Giriş: Kişisel sağlık verilerinin korunması yaşam hakkıyla doğrudan ilişkili olmasına rağmen günümüzde hasta mahremiyetini sağlamak oldukça güçtür. Amaç: Bu araştırma, hemşirelik öğrencilerinin hastaların kişisel sağlık verilerinin kayıt ve korunmasına yönelik tutumlarını belirlemek amacıyla yapılmıştır. Yöntem: Araştırma 2019-2020 Eğitim-Öğretim yılının Güz yarıyılında bir üniversitenin Sağlık Bilimleri Fakültesi Hemşirelik Bölümü’ndeki 454 öğrenci ile yapılmış tanımlayıcı kesitsel tipte bir çalışmadır. Veriler; “Öğrenci Tanıtım Formu” ve "Hemşirelik Öğrencileri İçin Kişisel Sağlık Verilerinin Kayıt ve Korunması Tutum Ölçeği (KSVKKTÖ)" kullanılarak toplanmıştır. Veriler Mann Whitney U testi ve Kruskal Wallis testi ile değerlendirilmiş olup, tanımlayıcı özellikler ortalama, yüzdelik olarak verilmiştir. Bulgular: "Hemşirelik Öğrencileri İçin Kişisel Sağlık Verilerinin Kayıt ve Korunması Tutum Ölçeği” toplam puan ortalamasının $4.06 \pm 0.51$ olduğu bulunmuştur. Beş alt boyuttan oluşan ölçekte öğrencilerin en yüksek puanı $4.11 \pm 0.58$ puan ortalaması ile "Kişisel Sağlık Verisi Bilgisi”" alt

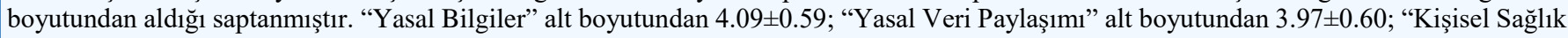
Verisi Paylaşımı" alt boyutundan 3.96 \pm 0.61 ; "Kişisel Sağlık Verisi Kaydı" alt boyutundan $4.09 \pm 0.63$ puan aldığ 1 saptanmıştır. Çalışmada ölçeğin Cronbach alpha değeri .91 olarak bulunmuştur. Sonuç: Araştırma sonuçlarına göre, hemşirelik öğrencilerinin kişisel verilerin kaydı ve korunmasına ilişkin tutumlarının olumlu olduğu ve farkındalıklarının yüksek olduğu saptanmıştır.

Anahtar Sözcükler: Hemşirelik Öğrencisi, Kişisel Sağlık Verisi, Tutum.

\section{Abstract}

Attitudes of Nursing Students Related the Registration and Preservation of Personal Health Data of Patients

Background: Preservation of personal health data is directly related to the right to live. However, it is very difficult to ensure patient privacy nowadays. Objectives: This research was conducted to determine the attitudes of nursing students towards the registration and preservation of patients' personal health data. Methods: The research is a descriptive cross-sectional study with 454 students registered in the Faculty of Health Sciences Nursing Department of a university in the fall semester of the 2019-2020 academic year. Data were collected using the "Student Identification Form" and "Registration and Preservation of the Personal Health Data Attitude Scale For Nursing Students". The data were evaluated by the Mann Whitney U test and Kruskal Wallis test. The descriptive features were given as mean, percentages. Results: The mean total score of the "Registration and Preservation of the Personal Health Data Attitude Scale For Nursing Students" was found to be $4.06 \pm 0.51$. In the scale consisting of five sub-dimensions, it was found that the students obtained the highest score from the "Personal Health Data Information" sub-dimension with the mean score 4.11 \pm 0.58 ; $4.09 \pm 0.59$ scores from the "Legal Information" sub-dimension, $3.97 \pm 0.60$ scores from the "Legal Data Sharing" sub-dimension; 3.96 \pm 0.61 scores from the "Personal Health Data Sharing" sub-dimension; $4.09 \pm 0.63$ scores from the "Personal Health Data Registration" sub-dimension. In the study, Cronbach alpha value of the scale was found to be .91. Conclusion: According to the results of the research, it was found that nursing students' attitudes towards registering and preserving personal data were positive and their awareness was high.

Key Words: Nursing Student, Personal Health Data, Attitude.

Geliş Tarihi / Received: 12.08.2020 Kabul Tarihi / Accepted: 22.05 .2021

Correspondence Author: Arş. Gör., Manisa Celal Bayar Üniversitesi Sağlık Bilimleri Fakültesi, Hemşirelik Esasları Anabilim Dalı, Uncubozköy Kampüsü/Manisa, E-mail: sevgis210188@hotmail.com, Tel: 5555725633

Cite This Article: Pakiş Çetin S, Çevik K. Hemşirelik öğrencilerinin hastaların kişisel sağlık verilerinin kayıt ve korunmasına ilişkin tutumları 2021; 14(3): 199- 206

Not: Bu çalışma, 20-21 Haziran 2020 tarihinde İzmir'de düzenlenen Uluslararası Sağlı Bilimleri Kongresi (ICHES-IDU 2020)’nde sözel bildiri olarak sunulmuştur. 
$\mathbf{T}$ Tarih boyunca tıbbi antlarda ve etik kodlarda yer alan "mahremiyet ve mahremiyetin korunması" kavramları "insan onuruna saygı" anlayışının önemli göstergelerindendir. Sağlık profesyonellerinin "insan onuruna saygı" anlayışı kişisel bilgilerin korunmasına yönelik görevlerini oluşturmaktadır (1). Günümüz modern tıbbında; teknolojik gelişmeler, bilgilerin saklanması ve gizliliğin korunması gibi konular dikkate alındığında, hasta mahremiyetini sağlamanın oldukça güç bir konu olduğu görülmektedir (2). Geleceğin sağlık profesyonelleri olacak hemşirelik öğrencilerine hasta mahremiyetini sağlama konusunda önemli roller düşmektedir (3). Hemşirelik öğrencilerinin kuramsal ve klinik uygulamalarından oluşan eğitim süreci; temel mesleki değerlerin ve etik ilkelerin benimsenmesi ve etik duyarlılığın geliştirilmesi açısından oldukça önemlidir (4).

Sağlık hizmeti gün geçtikçe hasta, hekim ve sağlık çalışanları çemberinden çıkarak diğer çalışanları da kapsayan bir alana dönüşmektedir. Sağlık bilişim teknolojilerindeki gelişmeler ise sağlık bilgilerine erişebilen kişi sayısının artmasına neden olmaktadır (5). Bu durum sağlık kurumlarındaki hekim, hemşire, ebe, hasta kayıt çalışanı, güvenlik görevlisi, bilgisayar işletmeni gibi tüm sağlık çalışanlarının kişisel verilerle ilgili suçların faili konumunda bırakılabilmelerini beraberinde getirmektedir $(6,7)$. Kişisel veri, 07.04.2016 tarihli 29677 sayılı Resmi Gazete'de yayımlanan, 24.03.2016 tarihli 6698 sayılı kanunda "Kimliği belirli veya belirlenebilir gerçek kişiye ilişkin her türlü bilgi" olarak tanımlanmıştır (8). Tanımda yer alan her türlü bilgi; kişinin adı, soyadı, cinsiyeti, yaşı, vatandaşlık numarası, doğum yeri, aile bilgileri, fiziksel özellikleri, mesleği, adresi, telefon numarası, motorlu taşıt plakası, pasaport numarası, özgeçmiş, banka bilgileri, IP adresi, mail veya sosyal medya paylaşımları, fotoğraf, sesli veya görüntülü video kayıtları, sağlık durumu kayıtları, biyometrik yöntemlerle elde edilen veriler ve parmak izi gibi kişiyi belirlenebilir kılan tüm verileri kapsamaktadır (7,9,10). Kişisel sağlık verisi ise, 24.11.2017 tarihli 30250 sayılı Resmi Gazete'de yayımlanan, Sağlık Bakanlığı tarafından yürürlüğe konan yönetmelikte, "kimliği belirli veya belirlenebilir gerçek kişinin fiziksel ve ruhsal sağlığına ilişkin her türlü bilgi ile kişiye sunulan sağlık hizmeti ile ilgili bilgiler" şeklinde açıklanmıştır (11). Kişisel sağlık verisi, kişinin sağlık hizmeti aldığı süreçte kaydedilen anamnez, muayene bulgusu, teşhis, epikriz, sağlık raporu, görüntüleme yöntemleri dahil tüm tahlil ve tetkik sonuçları, tedavide kullanılan ilaçlar, her türlü tıbbi girişim ve bakım uygulamalarına ait bilgileri içermektedir (7).

Teknolojinin gelişmesi, yaşamı kolaylaştırmayı ve kişiyi özgürleştirmeyi sağlamakla birlikte kişinin izlenmesi ve verilerinin kaydedilmesi "gözetim toplumu" endişesini de beraberinde getirmektedir. Bu kapsamda, bilgi aktarımının kolaylaştığı bir toplumda kişinin kendine ait veriler üzerindeki kontrol ve denetimini kaybetmesi gibi riskler sağlık alanında da karşımıza çıkmaktadır $(1,12)$. Sağlık hizmetlerindeki kalite çalışmaları da sağlık ve tedavi verilerinin kayıt altına alınması gerekliliğini ortaya koymaktadır. Bu kayıtların bilgisayar ortamında yapılması bu verilere ulaşmanın kolay olmasını sağlamakla birlikte; bu verilerin amaç dışı kullanımı, sağlık gibi temel haklara erişim sebepleriyle kişinin onamıyla üçüncü kişilerle verilerin paylaşılması ya da hasta mahremiyetine dikkat edilmemesi gibi bazı sorunları da beraberinde getirmektedir. Bu noktadan sonra verilere yetkisiz erişim, verilerin yayılması, yetkisiz kullanımı gibi güvenlik sorunları gündeme gelmektedir $(1,13)$. Kişisel verilerle ilgili suçlar arasında; hastaya ait kayıtların amacı dışında, hukuka uygunsuz olarak kaydedilmesi, hastanın rızası olmaksızın başka kişilere verilmesi, medya ve sosyal medya paylaşımları gibi davranışlar yer almaktadır. Ayrıca sağlık verilerinin korunması doğrudan yaşam hakkıyla ilişkili bir alan olduğundan verileri kayıt eden görevlinin öğrendiği tüm verilerin mahremiyetini koruma yükümlülüğü de bulunmaktadır $(7,14)$. Kişisel sağlık verilerinin korunmadığı, sınırsız bir şekilde toplandığ 1 , kullanıldığı, kayıt edildiği, işlendiği bir ortamda kişinin, başta ayrımcılık olmak üzere çeşitli tehlikelerle karşılaşma ihtimali artmakla birlikte, bu durum giderilmesi imkansız daha büyük sorunlara da sebep olabilmektedir. Bunun yanısıra kişisel sağlık verilerinin korunması yaşam hakkıyla da doğrudan ilişkilidir (14).

Ülkemizde hemşirelik öğrencilerinin kişisel sağlık verilerinin kayıt ve korunmasına yönelik tutum ve davranışlarının incelendiği yalnızca bir çalışmaya rastlanmıştır. Öğrenci hemşirelerin kişisel sağlık verilerinin kayıt ve korunmasına yönelik tutumlarının incelenmesi amacıyla yapılan araştırma sonucu literatüre katkı sağlayarak; ülkemiz ve yurt dışında bu konuyla ilgili yapılacak çalışmalara 1şık tutacaktır.

\section{Araștırmanın Soruları}

- Hemşirelik öğrencilerinin hastaların kişisel sağlık verilerinin kayıt ve korunmasına ilişkin tutumları nasıldır?

- Hemşirelik öğrencilerinin hastaların kişisel sağlık verilerinin kayıt ve korunmasına ilişkin farkındalık düzeyleri nedir?

- Hemşirelik öğrencilerinin hastaların kişisel sağlık verilerinin kayıt ve korunmasına ilişkin tutumları ile sosyodemografik özellikleri, hemşirelik bölümünü isteyerek tercih etme durumu, uygulama alanlarında çalışmayı sevme durumu ve hastalarla iletişim düzeyi, kişisel veri ve kişisel sağlık verisi kavramını daha önce duyma durumu arasında ilişki var mıdır?

\section{Yöntem}

\section{Araștırmanın Tipi}

Tanımlayıcı kesitsel tipte bir çalı̧̧madır.

\section{Araştırmanın Yapıldı̆̆ Yer}

Araştırma Eylül-Ekim 2019 tarihleri arasında bir üniversitenin hemşirelik bölümünde eğitim gören ikinci, üçüncü ve dördüncü sınıf öğrencileriyle yapılmıştır.

\footnotetext{
Araştırmanın Değiş̧kenleri

Araştırmanın bağımlı değişkeni çalışma kapsamındaki öğrencilerin "Hemşirelik Öğrencileri İçin Kişisel Sağlık Verilerinin Kayıt ve Korunması Tutum Ölçeğì" puan ortalamalarıdır. Araştırmanın bağımsız değişkenleri ise çalışma kapsamındaki öğrencilerin sosyo-demografik özellikleri, hemşirelik bölümünü isteyerek tercih etme durumu, uygulama alanlarında çalı̧̧mayı sevme durumu ve hastalarla iletişim düzeyi, kişisel veri ve kişisel sağlık verisi kavramını daha önce duyma durumudur.
}

Araștırmanın Evreni/Örneklemi 
Araştırmanın evrenini, 2019-2020 eğitim öğretim yılında bir üniversitenin Sağlık Bilimleri Fakültesi Hemşirelik Bölümünde eğitim gören ikinci, üçüncü ve dördüncü sınıfta okuyan toplam 596 öğrenci oluşturmuştur. Araştırmanın örneklemini ise; araştırmaya katılmayı kabul eden, en az bir yıl hemşirelik eğitimi almış, klinik uygulama deneyimi olan 454 öğrenci oluşturmuştur. Altı öğrenci anketi eksik doldurduğu için araştırmadan çıkartıldı. Sonuç olarak; evrenin \% 76 'sına ulaşılmıştır.

\section{Veri Toplama Araçları}

Veriler öğrencilerin ders aralarında araştırmacılar tarafından veri toplama formlarının her sınıftaki öğrenciye elden dağıtılması ve öğrencilerin formları doldurmalarının ardından tekrar araştırmacılar tarafından geri teslim alınmasıyla toplanmıştır. Verilerin toplanmasında; "Bilgilendirilmiș Gönüllü Olur Formu” ile öğrencilerin onamı alındıktan sonra "Öğrenci Tanıtım Formu" ve "Hemşirelik Öğrencileri İçin Kişisel Sağlık Verilerinin Kayıt ve Korunması Tutum Ölçeği (KSVKKTÖ)” kullanılmıştır.

\section{Veri Toplama Araçlart}

Verilerin toplanmasında; "Bilgilendirilmiş Gönüllü Olur Formu" ile öğrencilerin onamı alındıktan sonra "Öğrenci Tanıtım Formu" ve "Hemşirelik Öğrencileri İçin Kişisel Sağlık Verilerinin Kayıt ve Korunması Tutum Ölçeği (KSVKKTÖ)" kullanılmıştır.

\section{Ögrenci Tanıtım Formu}

Öğrencilerin sosyodemografik özellikleri, hemşirelik mesleği ve kişisel sağllk verisine yönelik hazırlanan bu formda; öğrencinin yaşı, sınıfı, cinsiyeti, mezun olduğu lise, en uzun süre yaşadığ ve çalışma durumu, baba eğitim düzeyi, baba mesleği ve çalışma durumu, aile gelir düzeyi, hemşirelik bölümünü isteyerek tercih etme durumu, uygulama alanlarında çalışmayı sevme durumu ve hastalarla iletişim düzeyi, kişisel veri ve kişisel sağlık verisi kavramını daha önce duyma durumunu içeren 18 soru bulunmaktadır.

\section{Hemşirelik Öğrencileri Için Kişisel Sağlık Verilerinin Kayıt ve Korunması Tutum Ölçeği (KSVKKTÖ)}

Gözmener ve arkadaşları (2019) tarafından geliştirilen, geçerlik ve güvenirlik çalışması yapılan ölçek Kişisel Sağlık Verisi Bilgisi (1-12 arası maddeler), Yasal Bilgiler (13-19 arası maddeler), Yasal Veri Paylaşımı (20-24 arası maddeler), Kişisel Sağlık Verisi Paylaşımı (25-28 arası maddeler), Kişisel Sağlık Verisi Kaydı (29-31 arası maddeler) olmak üzere beş alt boyut ve 31 maddeden oluşmaktadır. Ölçekte tersten puanlanan madde olmamakla birlikte maddelerin değerlendirilmesinde; "1- kesinlikle katılmıyorum, 2- katılmıyorum, 3- fikrim yok, 4- katılıyorum, 5- kesinlikle katılıyorum” olmak üzere beşli likert tipi değerlendirme kullanılmıştır.

Ölçek toplam puanı hesaplaması ve değerlendirmesi, tüm alt boyutlar için de aynı şekilde kabul edilmektedir. Ölçeğin kesme noktası 3 olarak belirlenmiştir. Ölçekten ortalama 3'ün altında puan alan öğrencilerin kişisel verilerin kaydı ve korunmasına ilişkin tutumları olumsuz, 3 ve üzeri puan alan öğrencilerin kişisel verilerin kaydı ve korunmasına ilişkin olumlu olarak değerlendirilmektedir. Olumsuz tutum; öğrencilerin kişisel verilerin kaydı ve korunmasına ilişkin farkındalığının düşük olduğunu gösterirken, olumlu tutum; farkındalığın yüksek olduğunu göstermektedir. Ölçeğin Cronbach alpha güvenirlik katsayısı .94 olarak bulunmuştur (7). Bu araştırmada ölçeğin Cronbach alpha değeri .91, ölçeğin alt boyutlarında yer alan Kişisel Sağlık Verisi Bilgisi, Yasal Bilgiler, Yasal Veri Paylaşımı, Kişisel Sağlık Verisi Paylaşımı, Kişisel Sağlık Verisi Kaydı Cronbach alpha değerleri sırasıyla $.78, .81, .73, .68, .76$ olarak saptanmıştır.

\section{Verilerin Toplanmast}

Veriler öğrencilerin ders aralarında araştırmacılar tarafından veri toplama formlarının her sınıftaki öğrenciye elden dağıtılması ve öğrencilerin formları doldurmalarının ardından tekrar araştırmacılar tarafından geri teslim alınmasıyla toplanmıştır. Verilerin toplanması yaklaşık 10 dakika sürmüştür.

\section{Verilerin Değerlendirilmesi}

Araştırma sonucunda elde edilen veriler araştırmacılar tarafından bilgisayar ortamında ve istatistiksel çözümlemeler için Statistical Package For Social Science (SPSS) 21.0 programı kullanılarak değerlendirilmiştir. Kolmogorov-Smirnov analizi sonucunda verilerin normal dağılım göstermediği tespit edildiğinden analizlerde nonparametrik testler kullanılmıştır. Veriler Mann Whitney U testi ve Kruskal Wallis testi ile değerlendirilmiş olup, tanımlayıcı özellikler ortalama, yüzdelik olarak gösterilmiştir.

\section{Araştırmanın Etik Yönü}

$\mathrm{Bu}$ araştırmanın yapılabilmesi için araştırmanın yapıldığı kurumdan, bir üniversitenin Tıp Fakültesi Sağlık Bilimleri Etik Kurulu'ndan (Tarih/Sayı: 22.05.2019/ 20.478.486), ölçeğin geçerlik-güvenirliğini yapan yazardan yazılı izin, araştırma kapsamına alınan öğrencilerden de yazılı ve sözlü onam alınmıştır. 


\section{Bulgular}

Tablo 1. Öğrencilerin Tanttıcı Özelliklerine Göre Dă̆ğlımı $(N=454)$

\begin{tabular}{|c|c|c|c|c|c|}
\hline Tanıtıcı Özellikler & $\mathbf{n}$ & $\%$ & Tanıtıcı Özellikler & $\mathbf{n}$ & $\%$ \\
\hline Cinsiyet & & & Anne Çalışma Durumu & & \\
\hline Kadın & 359 & 79.1 & Çalışıyor & 70 & 15.4 \\
\hline Erkek & 95 & 20.9 & Çalışmiyor & 384 & 84.6 \\
\hline Yaş Grubu & & & Baba Eğitim Düzeyi & & \\
\hline 21 yaş altı & 377 & 83 & Okuryazar değil & 4 & 0.9 \\
\hline 22 yaş ve üzeri & 77 & 17 & Okuryazar & 26 & 5.7 \\
\hline Yaș ortalaması & \multicolumn{2}{|c|}{$20.56 \pm 1.58$} & İlkokul & 211 & 46.5 \\
\hline \multicolumn{3}{|l|}{ Sinıf } & Lise ve üniversite & 213 & 46.9 \\
\hline İkinci sınıf & 172 & 37.9 & \multicolumn{3}{|l|}{ Baba Mesleği } \\
\hline Üçüncü sınıf & 151 & 33.3 & Memur ve işçi & 172 & 37.9 \\
\hline Dördüncü sınıf & 131 & 28.9 & Serbest meslek & 178 & 39.2 \\
\hline \multicolumn{3}{|l|}{ Mezun Olunan Lise } & Emekli & 104 & 22.9 \\
\hline Fen ve Anadolu Lisesi & 366 & 80.6 & \multicolumn{3}{|l|}{ Baba Çalışma Durumu } \\
\hline Meslek Lisesi & 42 & 9.3 & Çalışıyor & 317 & 69.8 \\
\hline \multirow{2}{*}{\multicolumn{3}{|c|}{$\begin{array}{l}\text { Diğer } \\
\text { En Uzun Süre Yaşanılan Yer }\end{array}$}} & Çalışmıyor & 137 & 30.2 \\
\hline & & & \multicolumn{3}{|l|}{ Aile Gelir Düzeyi } \\
\hline İl & 317 & 69.8 & Kötü-orta & 369 & 81.3 \\
\hline İlçe & 97 & 21.4 & İyi-çok iyi & 85 & 18.7 \\
\hline Köy & 40 & 8.8 & \multirow{2}{*}{\multicolumn{3}{|c|}{$\begin{array}{l}\text { Hemşirelik Bölümünü İsteyerek Tercih Etme } \\
\text { Durumu }\end{array}$}} \\
\hline \multicolumn{3}{|l|}{ İkamet Edilen Yer } & & & \\
\hline İl & 355 & 78.2 & Evet & 302 & 66.5 \\
\hline İlçe ve köy & 99 & 21.8 & Hayır & 152 & 33.5 \\
\hline Aile Yapısı & & & \multicolumn{3}{|c|}{ Uygulama Alanlarında Çalıșmayı Sevme Durumu } \\
\hline Çekirdek & 391 & 86.1 & Evet & 377 & 83 \\
\hline Geniş & 63 & 13.9 & Hayır & 77 & 17 \\
\hline \multicolumn{3}{|l|}{ Anne Eğitim Düzeyi } & \multicolumn{3}{|c|}{ Uygulama Alanlarında Hastalarla İletişim Düzeyi } \\
\hline Okuryazar değil & 33 & 7.3 & Kötü-orta & 158 & 34.8 \\
\hline Okuryazar & 30 & 6.6 & İyi-çok iyi & 296 & 65.2 \\
\hline 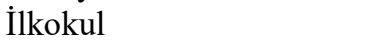 & 268 & 59 & & & \\
\hline Lise ve üniversite & 123 & 27.1 & \multirow{2}{*}{\multicolumn{3}{|c|}{$\begin{array}{l}\text { Kişisel Veri ve Kişisel Sağlık Verisi İfadesini İlk Kez } \\
\text { Duyma Durumu }\end{array}$}} \\
\hline \multicolumn{3}{|l|}{ Anne Mesleği } & & & \\
\hline Memur ve işçi & 46 & 10.1 & Evet & 160 & 35.2 \\
\hline Serbest meslek ve emekli & 30 & 6.6 & Hayır & 294 & 64.8 \\
\hline Ev hanımı & 378 & 83.3 & & & \\
\hline
\end{tabular}

Tablo 1'de öğrencilerin sosyodemografik özellikleri, hemşirelik mesleği ve kişisel sağlık verisine yönelik düşüncelerine göre dağılımı yer almaktadır. Araştırmaya katılan öğrencilerin \%79.1'inin kadın, \%83'ünün 21 yaş altında, \%37.9'unun ikinci sınıf, \%80.6'sının Fen ve Anadolu lisesi mezunu, \%69.8'inin en uzun süre ilde yaşadığı, \%78.2'sinin ilde ikamet ettiği, \%86.1'inin çekirdek aile yapısına sahip olduğu, \%59'unun annesinin ilkokul mezunu, \%83.3'ünün ev hanımı olduğu ve \%84.6'sının çalışmadığı, \%46.9'unun babasının lise ve üniversite mezunu, \%39.2'sinin serbest meslek olarak ve \%69.8'inin çalıştığı, \%81.3’ünün aile gelir düzeyinin kötü-orta olduğu saptanmıştır. Öğrencilerin hemşirelik mesleğine ve kişisel veri, kişisel sağlık verisine ilişkin düşünceleri incelendiğinde; \%66.5'inin hemşirelik bölümünü isteyerek tercih ettiği, \%83'ünün uygulama alanlarında çalışmayı sevdiği, \%65.2’sinin hastalarla iletişiminin iyi-çok iyi olduğu ve \%64.8'inin kişisel veri ve kişisel sağlık verisi ifadesini daha önce duyduğu belirlenmiştir (Tablo 1).

Tablo 2. Hemşirelik Ö̆ğrencileri İçin Kişisel Sağlık Verilerinin Kayıt ve Korunması Tutum Ölçeği ve Alt Boyut Puan Ortalamaları $(N=454)$

\begin{tabular}{lll}
\hline $\begin{array}{l}\text { Hemşirelik Öğrencileri İçin Kişisel Sağlık Verilerinin } \\
\text { Kayıt ve Korunması Tutum Ölçeği Alt Boyutları }\end{array}$ & $\begin{array}{l}\text { Puan Aralı̆̆ı } \\
\text { (Min-Max) }\end{array}$ & Ort \pm SS \\
\hline Kişisel sağlık verisi bilgisi & $1-5$ & $4.11 \pm 0.58$ \\
Yasal bilgiler & $1-5$ & $4.09 \pm 0.59$ \\
Yasal veri paylaşımı & $1-5$ & $3.97 \pm 0.60$ \\
Kişisel sağlık verisi paylaşımı & $1-5$ & $3.96 \pm 0.61$ \\
Kişisel sağlık verisi kaydı & $1-5$ & $4.09 \pm 0.63$ \\
\hline Toplam puan & $4.06 \pm 0.51$ & \\
\hline
\end{tabular}

“Hemşirelik Öğrencileri İçin Kişisel Sağlık Verilerinin Kayıt ve Korunması Tutum Ölçeği” ve alt boyut puan ortalamaları Tablo 2'de yer almaktadır. "Hemşirelik Öğrencileri İçin Kişisel Sağlık Verilerinin Kayıt ve Korunması Tutum Ölçeği”" toplam puan 
ortalamasının $4.06 \pm 0.51$ olduğu bulunmuştur. Öğrencilerin en yüksek puanı $4.11 \pm 0.58$ puan ortalaması ile "Kişisel Sağlık Verisi Bilgisi” alt boyutundan aldığı saptanmıştır (Tablo 2).

Tablo 3. Ö̆grencilerin Tanıtıcı Özellikleri ile Hemşirelik Ö̆̆grencileri İçin Kişisel Să̆lık Verilerinin Kayıt ve Korunması Tutum Ölçeği ve Alt Boyut Puan Ortalamalarının Karşılaş̧ırılması ( $\mathrm{N}=454)$

\begin{tabular}{lllllll} 
Sosyodemografik & Kişisel sağlık & Yasal bilgiler & Yasal veri & Kişisel sağlık & Kişisel sağlık & Toplam \\
Özellikler & $\begin{array}{l}\text { verisi bilgisi } \\
\text { Ort } \pm S S\end{array}$ & Ort \pm SS & paylaşımı & verisi & verisi kaydı & Ort $\pm S S$ \\
& & & Ort $\pm S S$ & $\begin{array}{l}\text { paylaşımı } \\
\text { Ort } \pm S S\end{array}$ & Ort $\pm S S$ & \\
\hline
\end{tabular}

\begin{tabular}{|c|c|c|c|c|c|c|}
\hline \multicolumn{7}{|l|}{ Cinsiyet } \\
\hline Kadın & $4.10 \pm 0.57$ & $4.08 \pm 0.59$ & $3.94 \pm 0.58$ & $3.95 \pm 0.61$ & $4.09 \pm 0.63$ & $4.05 \pm 0.50$ \\
\hline \multirow[t]{3}{*}{ Erkek } & $4.15 \pm 0.64$ & $4.13 \pm 0.58$ & $4.09 \pm 0.65$ & $4.01 \pm 0.59$ & $4.12 \pm 0.65$ & $4.11 \pm 0.53$ \\
\hline & Z: -1.322 & $Z:-1.053$ & $Z:-2.564$ & $Z:-1.192$ & $Z:-0.643$ & $Z:-1.511$ \\
\hline & p: .186 & p: .292 & p: .010* & p: .233 & p: .520 & p: .131 \\
\hline \multicolumn{7}{|l|}{ Yaş Grubu } \\
\hline 21 yaş ve altı & $4.13 \pm 0.58$ & $4.10 \pm 0.60$ & $3.97 \pm 0.61$ & $3.97 \pm 0.61$ & $4.10 \pm 0.64$ & $4.08 \pm 0.51$ \\
\hline \multirow[t]{3}{*}{22 yaş ve üzeri } & $4.02 \pm 0.60$ & $4.05 \pm 0.55$ & $3.95 \pm 0.56$ & $3.89 \pm 0.57$ & $4.08 \pm 0.62$ & $4.01 \pm 0.48$ \\
\hline & $Z:-1.405$ & $Z:-1.003$ & $Z:-0.518$ & $Z:-1.187$ & $Z:-0.400$ & $Z:-1.216$ \\
\hline & p: .160 & p: .316 & p: .604 & p: .235 & p: .689 & p: .224 \\
\hline \multicolumn{7}{|l|}{ Sinıf } \\
\hline 2.sinıf & $4.13 \pm 0.57$ & $4.14 \pm 0.48$ & $3.99 \pm 0.54$ & $3.98 \pm 0.54$ & $4.09 \pm 0.55$ & $4.08 \pm 0.44$ \\
\hline 3.sinif & $4.20 \pm 0.59$ & $4.09 \pm 0.72$ & $3.97 \pm 0.68$ & $4.00 \pm 0.69$ & $4.19 \pm 0.68$ & $4.11 \pm 0.58$ \\
\hline \multirow[t]{3}{*}{ 4.sinif } & $4.00 \pm 0.58$ & $4.05 \pm 0.54$ & $3.94 \pm 0.58$ & $3.89 \pm 0.59$ & $3.99 \pm 0.66$ & $3.99 \pm 0.50$ \\
\hline & $X^{2}: 15.447$ & $X^{2}: 1.973$ & $X^{2}: 0.291$ & $X^{2}: 2.527$ & $X^{2}: 9.316$ & $X^{2}: 7.581$ \\
\hline & p: .000*** & p: .373 & p: .865 & p: .283 & p: .009** & p: .023* \\
\hline \multicolumn{7}{|c|}{ Hemşirelik Bölümünü İsteyerek Tercih Etme Durumu } \\
\hline Evet & $4.12 \pm 0.58$ & $4.09 \pm 0.58$ & $3.97 \pm 0.58$ & $3.98 \pm 0.57$ & $4.06 \pm 0.61$ & $4.07 \pm 0.49$ \\
\hline \multirow[t]{3}{*}{ Hayır } & $4.09 \pm 0.59$ & $4.11 \pm 0.61$ & $3.96 \pm 0.64$ & $3.93 \pm 0.67$ & $4.16 \pm 0.68$ & $4.06 \pm 0.54$ \\
\hline & $Z:-0.203$ & $Z:-1.017$ & $Z:-0.051$ & $Z:-0.546$ & $Z:-2.355$ & $Z:-0.698$ \\
\hline & p: .839 & p: .309 & p: .960 & p: .585 & p: .019* & p: .485 \\
\hline \multicolumn{7}{|c|}{ Uygulama Alanlarında Çalışmayı Sevme Durumu } \\
\hline Evet & $4.12 \pm 0.57$ & $4.09 \pm 0.59$ & $3.96 \pm 0.60$ & $3.97 \pm 0.60$ & $4.09 \pm 0.62$ & $4.07 \pm 0.50$ \\
\hline \multirow[t]{3}{*}{ Hayır } & $4.06 \pm 0.64$ & $4.10 \pm 0.56$ & $4.01 \pm 0.61$ & $3.90 \pm 0.63$ & $4.11 \pm 0.67$ & $4.04 \pm 0.52$ \\
\hline & $Z:-0.366$ & $Z:-0.118$ & $Z:-0.687$ & $Z:-1.082$ & $Z:-0.674$ & $Z:-0.197$ \\
\hline & p:.714 & p: .906 & p: .496 & p: .279 & p: .500 & p: .844 \\
\hline \multicolumn{7}{|c|}{ Uygulama Alanlarında Hastalarla İletişim Düzeyi } \\
\hline Kötü-orta & $4.00 \pm 0.56$ & $4.02 \pm 0.52$ & $3.86 \pm 0.55$ & $3.85 \pm 0.59$ & $4.01 \pm 0.58$ & $3.96 \pm 0.46$ \\
\hline \multirow[t]{3}{*}{ İyi-çok iyi } & $4.18 \pm 0.59$ & $4.14 \pm 0.62$ & $4.02 \pm 0.62$ & $4.02 \pm 0.61$ & $4.14 \pm 0.66$ & $4.12 \pm 0.52$ \\
\hline & $Z:-1.734$ & $Z:-1.549$ & $Z:-0.762$ & $Z:-0.834$ & $Z:-1.728$ & Z: -1.322 \\
\hline & p: .083 & p: .121 & p: .446 & p: .404 & p: .084 & p: .186 \\
\hline \multicolumn{7}{|c|}{ Kişisel Veri ve Kişisel Sağlık Verisi İfadesini İlk Kez Duyma Durumu } \\
\hline Evet & $4.08 \pm 0.49$ & $4.05 \pm 0.62$ & $3.93 \pm 0.59$ & $3.89 \pm 0.57$ & $4.03 \pm 0.66$ & $4.02 \pm 0.49$ \\
\hline \multirow[t]{3}{*}{ Hayır } & $4.13 \pm 0.63$ & $4.12 \pm 0.57$ & $3.99 \pm 0.60$ & $4.00 \pm 0.63$ & $4.13 \pm 0.62$ & $4.09 \pm 0.53$ \\
\hline & Z: -1.272 & $Z:-0.870$ & Z: -0.853 & Z: -2.017 & Z: -1.291 & Z: -1.304 \\
\hline & p: .203 & p: .384 & p: .393 & p: .044* & p: .197 & p: .192 \\
\hline
\end{tabular}

Z: Mann Whitney U, $X^{2}$ : Kruskal Wallis $\quad{ }^{*} \mathrm{p}<.05 \quad{ }^{* *} \mathrm{p}<.01 \quad{ }^{* * *} \mathrm{p}<.001$

Öğrencilerin sosyodemografik özelliklerine göre "Hemşirelik Öğrencileri İçin Kişisel Sağlık Verilerinin Kayıt ve Korunması Tutum Ölçeği” ve alt boyutlarının toplam puan ortalamalarının dağılımı Tablo 3’te yer almaktadır.

"Hemşirelik Öğrencileri İçin Kişisel Sağlık Verilerinin Kayıt ve Korunması Tutum Ölçeği” ve alt boyut puan ortalamaları sosyodemografik özellikler ile karşılaştırıldığında; cinsiyet ile yasal veri paylaşımı alt boyutu arasında istatistiksel olarak anlamlı bir fark olduğu $(\mathrm{p}<.05)$; sınıf ile kişisel sağlık verisi bilgisi ve kişisel sağlık verisi kaydı alt boyutları ile ölçek toplam puan ortalaması arasında anlamlı bir fark olduğu $(\mathrm{p}<.05)$; hemşirelik bölümünü isteyerek tercih etme durumu ile kişisel sağlık verisi kaydı alt boyutu arasında anlamlı bir fark olduğu $(\mathrm{p}<.05)$; kişisel sağlık verisi ifadesini ilk kez duyma durumu ile kişisel sağlık verisi paylaşımı alt boyutu arasında istatistiksel olarak anlamlı bir fark olduğu saptanmıştır (p <.05, Tablo 3).

Yaş grubu, uygulama alanlarında çalışmayı sevme durumu, uygulama alanlarında hastalarla iletişim düzeyi ile Hemşirelik Öğrencileri İçin Kişisel Sağlık Verilerinin Kayıt ve Korunması Tutum Ölçeği toplam puanı ve alt boyut puan ortalamaları arasında istatistiksel olarak anlamlı bir fark olmadı̆̆ saptanmıştır ( $>$ > .05, Tablo 3). 
Kişisel sağlık verilerinin korunması yaşam hakkıyla doğrudan ilişkilidir (14). Çalışmamızda öğrencilerin "Hemşirelik Öğrencileri İçin Kişisel Sağlık Verilerinin Kayıt ve Korunması Tutum Ölçeği” toplam puan ortalamasının ortalamanın üzerinde olduğu saptanmıştır. Büyük ve Baydın'ın (2020) çalışmasında, öğrencilerin kişisel sağlık verilerinin kayıt ve korunmasına yönelik puan ortalamalarının yüksek olduğu bildirilirken (15); Yıldız ve Atasoy'un (2016) çalışmasında ise öğrencilerin bilgi güvenliği farkındalık düzeylerinin yüksek olduğu belirtilmiştir (16). Literatürde öğrencilerin hasta mahremiyetine yönelik tutumlarının, hasta hakları algısının ve dolayısıyla farkındalıklarının yüksek olduğunu bildiren çalışmalar da bulunmaktadır (3,17-21). Çalışmamızın sonuçları, literatürdeki çalışma sonuçlarını destekler niteliktedir. Çalışmamızda öğrencilerin kişisel verilerin kaydı ve korunmasına ilişkin olumlu tutum geliştirdikleri ve farkındalıklarının yüksek olduğu söylenebilir.

Öğrencilerin ölçek alt boyutlarından en yüksek puanı "Kişisel Sağlık Verisi Bilgisi” alt boyutundan aldığı saptanmıştır. Büyük ve Baydın (2020)'ın çalışmasında da, öğrencilerin “Kişisel Sağlık Verisi Bilgisi” alt boyutu puan ortalamalarının yüksek olduğu bildirilmiştir (15). Soysal ve Kuşçu (2018) ile Zengin ve Hasgül'ün (2019) çalışmalarında, öğrencilerin hasta haklarına ilişkin bilgi düzeyinin ortalamanın üzerinde olduğu saptanmıştır $(20,22)$. Literatürdeki diğer çalışmalarda öğrencilerin hasta haklarına ilişkin bilgi düzeyinin ortalamanın üzerinde olduğu saptanmıştır (20,22-24). Çalışmamız ile bu çalışma sonuçları benzerlik göstermektedir. Çalışmamızın sonucu, araştırmamıza katılan öğrencilerin daha önceden bu kavramı duyduklarını ve klinik alanda kullandıklarını düşündürmektedir.

Cinsiyet ile ölçek alt boyutlarından olan "Yasal Veri Paylaşımı” puan ortalamasının gruplar arasında istatistiksel olarak farklı olduğu saptanmıştır. Soysal ve Kuşçu'nun (2018) çalışmasında, öğrencilerin cinsiyet değişkeninin hasta hakları bilgi düzeylerini etkilediği ve erkeklerin kadınlara göre daha yüksek puan aldıkları bildirilmiştir (20). Çalışmamız; bu çalışma sonucu ile benzerlik göstermektedir. Literatürdeki diğer çalışmalarda öğrencilerin yasal veri paylaşımı ya da hasta hakları bilgi düzeyi puan ortalamalarının cinsiyete göre farklılaştığ 1 ; kadınların puan ortalamalarının erkeklerden daha yüksek olduğu bildirilmiştir (15,21-23). Öztürk ve ark. (2018), Al Anazi ve ark. (2019), Özkan ve ark.'nın (2020) çalışmalarında ise, cinsiyetin hasta haklarına ilişkin farkındalık üzerinde etkisi olmadığı bildirilmiştir $(3,24,25)$. Çalışmamızın sonuçları, bu çalışmalarla benzerlik göstermemektedir. Çalışmamızda erkek öğrencilerin alt boyut puan ortalamalarının kadınlardan yüksek olduğu görülmektedir. $\mathrm{Bu}$ farkın; çalışmanın yapıldığı örneklemdeki öğrencilerin kültürel ve kişisel özelliklerinden kaynaklanmış olabileceği düşünülmektedir.

Öğrenciler öğrenim gördükleri sınıflara göre incelendiğinde; "Kişisel Sağlık Verisi Bilgisi”, "Kişisel Sağlık Verisi Kaydı" alt boyutları ve toplam ölçek puanı açısından gruplar arasında istatistiksel olarak anlamlı fark olduğu saptanmıştır. Büyük ve Baydın (2020)'ın çalışmasında, öğrencilerin “Kişisel Sağlık Verisi Bilgisi” alt boyutu ile toplam ölçek puanı açısından gruplar arasında istatistiksel olarak anlamlı fark olduğu bildirilmiştir (15). Çalışmamız; bu çalışma sonucu ile benzerlik göstermektedir. Yıldız ve Atasoy’un (2016) çalışmasında, ikinci sınıftaki öğrencilerin bilgi güvenliği farkındalık düzeylerinin istatistiksel olarak daha yüksek olduğu belirtilmiştir (16). Hosseini-Ghavam-Abad ve ark. (2019) ile Al Anazi ve ark.'nın (2019) çalışmalarında ise, hasta hakları ile ilgili bilgi düzeyinin en yüksek olduğu grubun son sınıf öğrencileri olduğu bildirilmiştir (23,24). Literatürdeki diğer çalışmalarda; sınıf değişkeninin hasta hakları ile ilgili bilgi düzeyi ya da mahremiyet koruma davranışları üzerinde etkili olmadığı belirlenmiştir $(3,20,21)$. Çalışmamızın sonuçları, bu araştırmaların sonuçlarını desteklememektedir. Çalışmamızda ölçek alt boyut ve toplam puan ortalamalarının en yüksek üçüncü sınıf öğrencilerde olduğu saptanmıştır. Bu farkın; üçüncü sınıf öğrencilerinin Hemşirelikte Etik ve Eleştirel Düşünme derslerini yakın zamanda almış olmalarına bağlı kişisel sağlık verilerinin gizliliği ve önemi konusuna değinilmiş olabileceğini düşündürmektedir. Dördüncü sınıf öğrencilerde ölçek alt boyut ve toplam puan ortalamalarının düşük olması ise öğrenilen bilgilerin kalıcılığının sağlanamadığını düşündürmektedir.

Araştırmaya katılan öğrencilerin yarısından fazlasının hemşirelik bölümünü isteyerek tercih ettiği görülmektedir. Öğrencilerin hemşirelik bölümünü isteme durumları ile ölçek alt boyut ve toplam puan ortalamaları karşılaştırıldığında; yalnızca "Kişisel Sağlık Verisi Kaydı" alt boyutu puan ortalaması açısından gruplar arasında istatistiksel olarak anlamlı bir fark olduğu saptanmıştır. Çalışmamızda ölçek toplam puanı açısından gruplar arasında farklılık olmadığı saptanmıştır. Soysal ve Kuşçu (2018) ile Demir ve ark.'nın (2021) çalışmalarında, öğrencilerin okudukları bölümü isteyerek tercih etme durumları ile hasta hakları bilgi düzeyleri ya da mahremiyet ölçeği puan ortalamaları arasında anlamlı fark olmadığı bildirilmiştir (20,21). Çalışmamızın sonuçları, bu araştırmaların sonuçlarını destekler niteliktedir. Çalışmamızda hemşirelik bölümünü isteyerek tercih etmeyen öğrencilerin farkındalıklarının daha yüksek olduğu bulunmuştur. Bu farkın; öğrencilerin klinik uygulamalarla birlikte mesleklerine karşı düşüncelerinde pozitif yönde değişim yaşadıklarından kaynaklandığı düşünülmektedir.

Öğrenciler klinik ortamda psikomotor becerilerin yanısıra mesleğin felsefesini kavramak, hasta haklarına saygı duymak, hasta haklarının savunuculuğunu yapmak gibi duyuşsal beceriler de geliştirmektedir (26). Araştırmaya katılan öğrencilerin tamamına yakını uygulama alanlarında çalışmayı sevdiğini beyan etmiştir. Öğrencilerin uygulama alanlarında çalışmayı sevme durumları ile ölçek alt boyut ve toplam puan ortalamaları karşılaştırıldığında istatistiksel olarak anlamlı bir fark olmadı̆̆ ve olumlu tutum geliştirdikleri görülmektedir. Bu durum, tüm öğrencilerin uygulama alanlarında duyuşsal becerileri kazanmış ve pekiştirmiş olabileceklerini düşündürmektedir.

Öğrencilerin yaklaşık üçte biri (\%35.2) kişisel veri ve kişisel sağlık verisi ifadesini ilk kez duyduğunu ifade etmiştir. Bu durum, öğrencilerin bir kısmının hasta hakları konusunda yeterince bilgiye sahip olmadığını düşündürmektedir.

Öğrencilerin kişisel veri ve kişisel sağlık verisi ifadesini ilk kez duyma durumu ile ölçek alt boyutlarından olan "Kişisel Sağlık Verisi Paylaşımı” puan ortalamasının gruplar arasında istatistiksel olarak farklı olduğu saptanmıştır. Kişisel sağlık verisi ifadesini daha önceden duyan öğrencilerin farkındalıklarının yüksek olduğu görülmektedir. Bu farkın; bilgi düzeyinden kaynaklandığg düşünülmektedir. 
Çalışmanın yalnızca bir üniversitenin Hemşirelik Bölümü’nde öğrenim gören, araştırmaya katılmayı kabul eden öğrenciler ile yürütülmüş olması ve "Hemşirelik Öğrencileri İçin Kişisel Sağlık Verilerinin Kayıt ve Korunması Tutum Ölçeği” kullanılarak yapılmış ikinci çalışma olması çalışmaya özgünlük kazandırırken aynı zamanda da tartışmada kullanılan kaynakların kısıtlı olması nedeniyle çalışmanın sınırlılıkları arasında yer almaktadır.

\section{Sonuçların Uygulamada Kullanımı}

Sonuç olarak, hemşirelik öğrencilerinin hastaların kişisel sağlık verilerinin kaydı ve korunmasına ilişkin olumlu tutum geliştirdikleri ve farkındalıklarının yüksek olduğu saptandı. Bu sonuç doğrultusunda;

- Kuramsal ve klinik uygulamalardan oluşan eğitim süreci içerisinde, müfredattaki zorunlu derslerde öğrencilerin kişisel veri ve kişisel sağlık verisi kavramları hakkında bilgilendirilmesi ile mevcut yüksek farkındalıklarının sürdürülmesi,

- Çalışmanın "Hemşirelik Öğrencileri İçin Kişisel Sağlık Verilerinin Kayıt ve Korunması Tutum Ölçeğı”” kullanılarak yapılmış ilk araştırmalardan biri olması nedeniyle, gelecekteki çalışmaların farklı üniversitelerde eş zamanlı olarak ve daha geniş örneklem gruplarıyla yapılması önerilebilir.

\section{Bilgilendirme}

Araştırma ile ilgili herhangi bir projeden ya da firmadan destek alınmamıştır. Araştırmanın bütçesi araştırmacılar tarafından karşılanmıştır. Yazarlar arasında herhangi bir çıkar çatışması yoktur. Ayrıca sorumlu olduğumuz araştırmada herhangi bir firma ile çıkar ilişkisi bulunmamaktadır. Araştırmanın yapılabilmesi için bir üniversitenin Tıp Fakültesi Sağlık Bilimleri Etik Kurulu'ndan 22.05.2019 tarih ve 20.478.486 karar nolu izin alınmıştır. Yazarların katkı oranı beyanı şu şekildedir: fikir S.P.Ç; tasarım K.Ç., S.P.Ç.; denetleme ve danışmanlık K.Ç.; veri toplama ve işleme S.P.Ç; analiz ve yorum S.P.Ç; kaynak taraması S.P.Ç; makalenin yazımı S.P.Ç; eleştirel düşünme ve değerlendirme K.Ç.

Çalışma boyunca sabırla destek veren tüm öğrencilere teşekkür ederiz. 


\section{Kaynaklar}

1. İzgi MC. (2014). Mahremiyet kavramı bağlamında kişisel sağlı verileri. TJOB 2014;1(1):25-37.

2. Berg JW. Patient confidentiality: Privacy and public health. Bioethics [online] 2011 . URL: http://www.thedoctorwillseeyounow.com/content/bioethics/art3401.html 16 Nisan 2019.

3. Özkan ZK, Eyi S, Mayda Z. Hemşirelik öğrencilerinin hasta mahremiyetini korumaya yönelik davranışlarının belirlenmesi. İnönü Üniversitesi Sağlık Hizmetleri Meslek Yüksekokulu Dergisi 2020;8(2):312-320.

4. Gürdoğan EP, Aksoy B, Kınıcı E. Hemşirelik öğrencilerinin etik duyarlılık düzeyleri ve mesleki değerler ile ilişkisi. SHYD 2018;5(3):147-154.

5. Küzeci E. Sağlık bilişism teknolojileri ve yeni hukuksal soru(n)lar. İnÜHFD 2018;9(1): 477-506.

6. Hakeri H. Tıp Hukuku. 11. Baskı. Ankara: Seçkin Yayıncılık; 2016.

7. Gözmener SB, Şenol S, İntepeler ŞS. Hemşirelik öğrencileri için kişisel sağlık verilerinin kayıt ve korunması tutum ölçeği geçerlik ve güvenirlik çalışması. DEUHFED 2019;12(1):21-30.

8. Kişisel Verilerin Korunması Kanunu (2016). URL: http://www.resmigazete.gov.tr/eskiler/2016/04/20160407-8.pdf 13 Nisan 2019

9. Kılınç D. Anayasal bir hak olarak kişisel verilerin korunması. AÜHFD 2012;61(3):1089-1172.

10. Korkmaz İ. Kişisel verilerin korunması kanunu hakkında bir değerlendirme. TBB Dergisi 2016;124:81-152.

11. Kişisel Sağlık Verilerinin İşlenmesi ve Mahremiyetinin Sağlanması Hakkında Yönetmelikte Değişiklik Yapılmasına Dair Yönetmelik (2017). URL: http://www.resmigazete.gov.tr/eskiler/2017/11/20171124-1.htm 13 Nisan 2019

12. Dülger MV. Sağlık hukukunda kişisel verilerin korunması ve hasta mahremiyeti. İMÜHFD 2015;1(2):43-80.

13. Özata M, Özer K. Sağlık çalışanlarının hasta mahremiyeti konusundaki tutumlarının incelenmesi. Hacettepe Sağlık İdaresi Dergisi 2017;20(1):1-21.

14. Küzeci E. Türkiye'de sağlık verilerinin korunması: Hukuksal çerçeve. Kişisel Sağlık Verileri Ulusal Kongresi; 19-20 Aralık 2015; İstanbul.

15. Büyük ET, Baydın NÜ. Hemşirelik öğrencilerinin etik duyarlılıkları ile kişisel sağlık verilerinin kayıt ve korunmasına yönelik tutumları arasındaki ilişki. TJOB 2021;7(4):198-210.

16. Yıldız NK, Atasoy A. 2016 Öğrencilerde bilgi güvenliği farkındalığının değerlendirilmesi. SPK 2016;(11):81-95.

17. Lee HJ. Convergence study on perception and performance of patient private information protection in nursing students with clinical practice. JCCT 2018;4(2):53-60. (Abstract)

18. Hwang JY, Choi H. Nursing students' human rights sensitivity and perception of patients' rights. J Korean Acad Soc Nurs Educ 2015;21(4):455-465. (Abstract)

19. Kim MS, Jeon MK. Influence of perception of patient rights and ethical values on biomedical ethics awareness in nursing students. Journal of East-West Nursing Research 2018;24(1):1-9.

20. Soysal A, Kuşcu FN. Hasta hakları: Üniversite öğrencileri üzerinde bir uygulama. Gümüşhane Üniversitesi Sağllk Bilimleri Dergisi 2018;7(1):102-111.

21. Demir H, Özyaral O, Biçer İ, Aydın, OA. Sağlık Hizmetleri Meslek Yüksekokulu öğrencilerinin hasta mahremiyeti konusundaki tutumlar1. SARAD 2021;3(1):23-30.

22. Zengin $\mathrm{O}$, Hasgül E. Evde hasta bakım programı öğrencilerinin etik duyarlılıkları ve hasta hakları bilgi düzeyleri üzerine bir araştırma. Ufkun Ötesi Bilim Dergisi 2019;19(1):43-53.

23. Hosseini-Ghavam-Abad L, Asghari F, Bandehagh A, Najafipour S, Bigdeli S. Patient privacy: Awareness and attitudes of Iran University of Medical Sciences medical students. MJIRI 2019;33(12):1-4.

24. Al Anazi BD, Faraj F, Al Balawi MM, Al Anazi MD. The awareness of Patients' Bill of Rights among medical interns and medical students at Tabuk University. Maced J Med Sci 2019;7(17):2932-2939.

25. Öztürk H, Akalın D, Avan H. Sağlık Hizmetleri Meslek Yüksekokulu öğrencilerinin hasta ve çocuk hakları bilgi düzeylerinin belirlenmesi. Kesit Akademi Dergisi 2018;15(4):274-281.

26. Aydoğan S. Hemşirelik öğrencilerinin klinik beceri kazanmaları sırasında karşılaştıkları etik problemler. TJOB 2016;3(2):120-123. 